\section{Onion Storage Decomposition Unaffected by Late-season Irrigation Reduction}

\author{
Clinton C. Shock, \\ Erik B.G. Feibert, and \\ Lamont D. Saunders
}

Additional index words. Allium cepa, drip irrigation, soil water potential, yield, grade, postharvest

Summary. L ong-day onion (Allium cepa L.) 'Vision' was submitted to four soil water potential (SWP) treatments using subsurface drip irrigation in 1997 and 1998. O nions were grown on two double rows spaced 22 inches $(56 \mathrm{~cm})$ apart on 44inch $(112-\mathrm{cm})$ beds with a drip tape buried 5 inches $(13 \mathrm{~cm})$ deep in the bed center. SWP was maintained at four levels by automated, high frequency irrigations based on SWP measurements at an 8 -inch $(20-\mathrm{cm})$ depth. The check treatment had SWP maintained at - 20 cbar ( $\mathrm{kPa}$ ) during the entire season. The other three treatments had SWP maintained at $\mathbf{- 2 0}$ cbar until $15 \mathrm{~J}$ uly, then reduced to $30,-50$, or -70 cbar. Reducing the SWP level after 15 July below -20 cbar failed to reduce onion bulb decomposition in storage, but reduced colossal onion yield in 1997, and marketable and total yield in 1998.

$\mathrm{T}$ he Treasure Valley of eastern Oregon and southwestern Idaho annually produces sweet Spanish onions on 22,000 acres (9000 ha). O nions grown in the Treasure Valley are classified as longday, and medium to long-term storage. $O$ nions are marketed starting at harvest in August and then from stor-

M alheur Experiment Station, O regon State U niversity, 595 O nion Avenue, O ntario, OR 97914; e-mail Clinton.Shock@orst.edu.

The cost of publishing this paper was defrayed in part by the payment of page charges. U nder postal regulations, this paper therefore must be hereby marked advertise ment solely to indicate this fact. age through A pril, so quality of stored onions is critical. Growing season weather is characterized by high onion crop evapotranspiration and low precipitation making irrigation essential.

Previous research with furrow irrigated onions at the $M$ alheur Experiment Station has shown that onions are sensitive to small water deficits and need frequent irrigations to maintain high SWP during the whole growing season for optimum yield and size (Shock et al., 1998a). Research with short day onions has shown similar results. Coelho et al. (1996) report an onion yield response to a threshold of -8.5 cbar ( $\mathrm{kPa}$ ) and Abreu et al. (1980) report an onion yield response to a threshold of - 10 cbar. Klar et al. (1976) report onion yields to be highest with the lowest threshold tested of -15 cbar. H owever, all studies with short day onions did not measure bulb decomposition in storage. Storage decomposition can be increased by high SWP (Shock et al., 1998a).

I rrigation management for optimum onion production with furrow irrigation can be difficult due to uneven irrigation and to the inability to avoid large oscillations in SWP. U nder furrow irrigation, areas at the top of the field, areas with more porous soil, and areas that are below grade can become wetter than the remainder of the field. Although the majority of onions in the Treasure Valley are furrow irrigated, drip irrigation isincreasing in popularity. The superior water application efficiency with subsurface drip irrigation allows for more precise irrigation management than with furrow irrigation. The use of automation with drip irrigation allowsfor frequent, light, and uniform irrigation so that the SWP can remain relatively constant compared to furrow irrigation. This trial tested the hypothesis that a reduction of SWP in the last third of the growing season could reduce storagedecomposition without appreciable reduction in bulb yield or size.

\section{Materials and methods}

Thetrialswereconducted in 1997 and 1998 at the $M$ alheur Experiment Station on O wyhee silt loam (coarsesilty, mixed, mesic, Xerollic Camborthid) previously planted to wheat. Seed of the yellow onion 'Vision' (Petoseed, Seminis Vegetable Seeds, Payette, I daho) was planted 1 inch $(2.5 \mathrm{~cm})$ deep in two double rows 
on 44-inch (112-cm) bedsin mid A pril. Each double row consisted of two onion rows spaced 2.4 inches $(6 \mathrm{~cm})$ apart with one seed per 4 inches ( 10 $\mathrm{cm})$ of row $(140,000$ seeds/ acre or 346,000 seeds/ ha). The two double rows were spaced 22 inches $(56 \mathrm{~cm})$ apart on the bed. D rip tape ( $N$ elson Pathfinder, N elson I rrigation Corp., Walla Walla, Wash.) was laid at the same time as planting at a 5-inch (13$\mathrm{cm}$ ) depth between the two double onion rows. Thedrip tape had emitters spaced 12 inches $(30 \mathrm{~cm})$ apart and a flow rate of $0.49 \mathrm{gal} / \mathrm{min}$ per $100 \mathrm{ft}$ (6.08 L $\cdot \mathrm{min}^{-1}$ per $\left.100 \mathrm{~m}\right)$ in 1997 and $0.24 \mathrm{gal} / \mathrm{min}$ per $100 \mathrm{ft}\left(2.67 \mathrm{~L} \cdot \mathrm{min}^{-1}\right.$ per $100 \mathrm{~m}$ ) in 1998. The field was sprinkler irrigated until onion emergence. O nions started emerging on 1 M ay 1997 and on 29 Apr. 1998.

I rrigation treatments were 1) SWP at an 8-inch $(20-\mathrm{cm})$ depth maintained at -20 cbar $(\mathrm{kPa})$ during the entireseason (check), and SWP at an 8-inch depth maintained at -20 cbar until 15 July, then reduced to 2) -30 cbar, 3) -50 cbar, and 4) $-70 \mathrm{cbar}$. The SWP was maintained constant by applying 0.06 inch $(1.5 \mathrm{~mm})$ of water up to eight times a day based on SWP readings every $3 \mathrm{~h}$. The irrigation treatments were started in early J une. The irrigation treatments were replicated five times and arranged in a randomized completeblock design. Plotswerefour double rows wide (88 inches or 224 $\mathrm{cm})$ by $50 \mathrm{ft}(15 \mathrm{~m})$ long.

Soil water potential was monitored in each plot by four Watermark soil moisture granular matrix sensors (GM Ss) (model 200SS; I rrometer C o., Riverside, Calif.) installed at an 8-inch depth. T he GM S were installed below one of the two onion double rows in the plot center. The sensors had been calibrated to SWP (Shock et al. 1998b).

The GM S were connected to the datalogger (CR 10 datalogger; C ampbell Scientific, Logan, U tah) via five multiplexers (AM 410 multiplexer, Campbell Scientific, Logan, U tah). A datalogger was programmed to read the GM S in each plot and, if necessary, irrigate the plots individually, according to the plot'sirrigation criteria. The irrigationswere controlled by the datalogger using a controller (SDM CD 16AC; Campbell Scientific, Logan, Utah) connected to solenoid valves in each plot. The pressure in the drip lines was maintained at $10 \mathrm{lb} /$ inch $^{2}(69 \mathrm{kPa})$ by individual pressure regulators for each plot. The amount of water applied to each plot was recorded daily from a water meter installed between the solenoid valve and the drip tape.

O nion crop evapotranspiration, $\mathrm{Et}_{\mathrm{c}^{\prime}}$ was calculated with a modified Penman equation (Wright, 1982) using data collected at the $M$ alheur Experiment Station by an Agrim et weather station (U .S. Bureau of Reclamation, Boise, Idaho). O nion $\mathrm{Et}_{\mathrm{c}}$ was estimated and recorded from crop emergence until the final irrigation. I rrigations were terminated on 29 Aug. 1997 and 10 Sept. 1998.

Theonionswereundercut with a rod weeder on 23 Sept. each year to allow field curing. In late September the onions in the central $40 \mathrm{ft}(12 \mathrm{~m})$ of the middle two double rows in each plot were topped and placed into storage. The storage shed was similar in design and operation to a commercial onion storage shed. Temperature was maintained at 34 to 40 ${ }^{\circ} \mathrm{F}\left(1\right.$ to $\left.4^{\circ} \mathrm{C}\right)$ and relative humidity near $70 \%$ O nions were graded out of storage on $15 \mathrm{Dec} .1997$ and on 2 Dec. 1998. Bulbs with any evidence of decomposition and split bulbs were separated before grading. Decomposed bulbs were not sorted according to causal organism due to the predominance of botrytis (Botrytisallii M unn.) in all treatments. About $75 \%$ of decomposition wasbotrytis and $25 \%$ was plate rot (Fusarium oxysporum Schlechtend.) both years with traces of black mold (A spergillusniger Tiegh.) in 1998. The bulbs were graded according to diameter: small $(<2.25$ inches or $57 \mathrm{~mm}$ ), medium (2.25 to 3 inchesor 57 to $76 \mathrm{~mm}$ ), jumbo ( 3 to 4 inches or 77 to $101 \mathrm{~mm}$ ), and colossal ( $>4$ inches or $101 \mathrm{~mm}$ ). M arketable onions were mediums, jumbos, and colossals. Total yield included decomposed and split bulbs. Data was analyzed by analysis of variance (N CSS

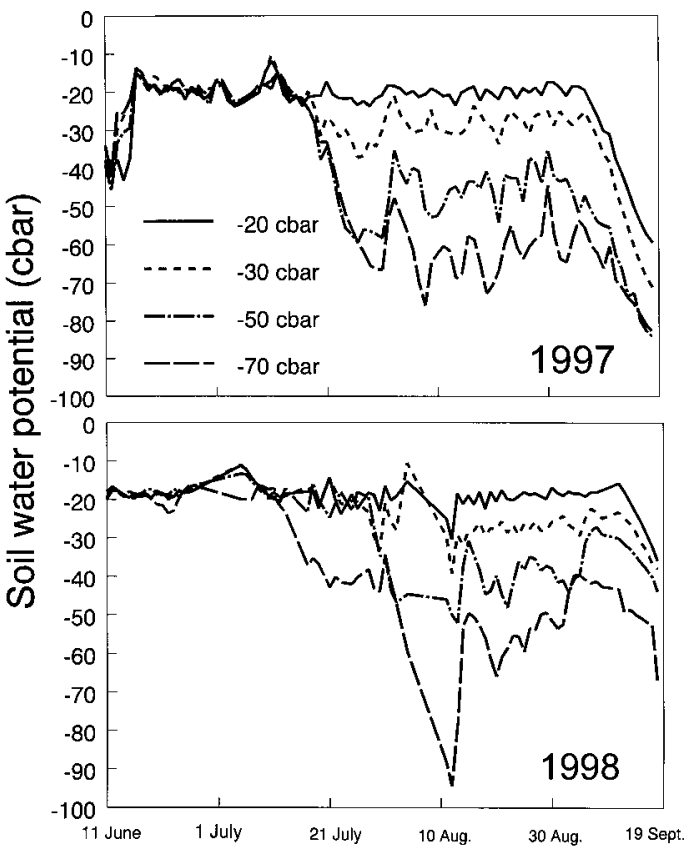

Fig. 1. Seasonal profile of soil water potential at an 8 -inch $(20-\mathrm{cm})$ depth for onions drip irrigated with a reduction in irrigation in the last third of the growing season; 1 cbar = $1 \mathrm{kPa}$.

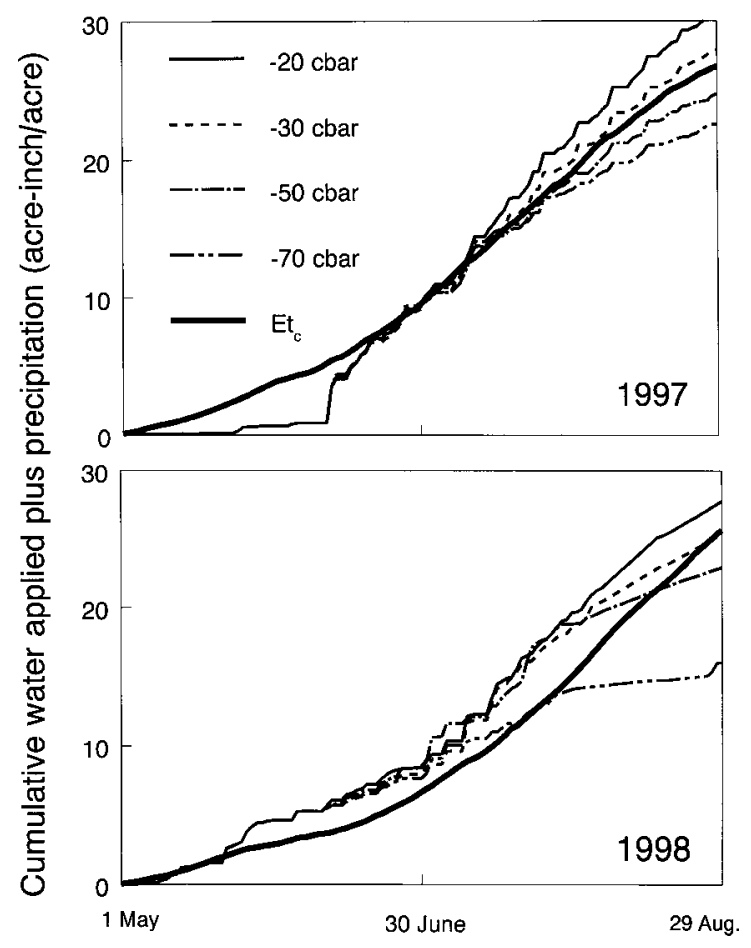

Fig. 2. C umulative water applied to drip irrigated onions compared with estimated crop evapotranspiration ( $\left.E t_{c}\right)$; $1 \mathrm{cbar}=1 \mathrm{kPa}, 1$ acre-inch/acre $=\mathbf{2 5 . 4}$ $\mathrm{mm}$. 
T able 1. Effect of reducing subsurface drip irrigation in the last third of the season on onion yield and quality. O nion yields were low in 1998 due to severe hail on 4 J uly.

\begin{tabular}{|c|c|c|c|c|c|c|c|c|c|c|}
\hline \multirow{3}{*}{$\begin{array}{l}\text { Soil water } \\
\text { potential } \\
\text { (cbar) } \\
\text { after 15 J uly }\end{array}$} & \multirow{2}{*}{\multicolumn{2}{|c|}{$\frac{\text { Decomposition }}{(\%)}$}} & \multicolumn{8}{|c|}{ Onion yield by market class (ton/acre) ${ }^{y}$} \\
\hline & & & \multicolumn{2}{|c|}{ Decomposition } & \multicolumn{2}{|c|}{ Colossal } & \multicolumn{2}{|c|}{ M arketable } & \multicolumn{2}{|c|}{ T otal yield } \\
\hline & 1997 & 1998 & 1997 & 1998 & 1997 & 1998 & 1997 & 1998 & & 1998 \\
\hline-20 & 1.7 & 2.0 & 0.8 & 0.4 & 19.7 & 0.25 & 44.1 & 23.7 & 46.7 & 24.9 \\
\hline-30 & 1.4 & 2.2 & 0.7 & 0.5 & 15.8 & 0.19 & 41.5 & 23.1 & 46.7 & 24.2 \\
\hline-50 & 2.1 & 5.2 & 1.0 & 1.0 & 13.5 & 0.03 & 44.8 & 17.2 & 47.9 & 19.1 \\
\hline-70 & 1.0 & 3.0 & 0.5 & 0.5 & 9.3 & 0.09 & 37.2 & 14.1 & 40.0 & 16.0 \\
\hline $\mathrm{LSD}_{\text {(005) }}$ & NS & 2.3 & NS & NS & 5.3 & NS & NS & 4.8 & NS & 4.5 \\
\hline
\end{tabular}

$\mathrm{z} 1 \mathrm{cbar}=1 \mathrm{kPa}$.

y1 ton/ acre $=2.24 \mathrm{t} \cdot \mathrm{ha}^{-1}$

6.0, N umber C runcher Statistical Systems, Kaysville, U tah).

\section{Results and discussion}

TheSWP remained relativelyconstant for all treatments until 15 July (Fig. 1). Growing season weather was characterized by Et averaging 28 inches $(699 \mathrm{~mm})$ and precipitation averaging 4.8 inches (122 mm) in 1997 and 1998. The amount of water applied (including precipitation) over time was slightly higher than $\mathrm{Et}$ for the full season -20 cbar treatment both years (Fig. 2). I rrigation plus precipitation was ahead of Et in 1998 due to excessive rainfall in late $M$ ay. For the treatment having SWP reduced to -30 cbar after 15 July, the total water applied was close to estimated $\mathrm{Et}_{\mathrm{c}}$. For the treatments having SWP reduced to -50 and -70 cbar after 15 July, the amount of water applied was lower than Et in 1997. In 1998 the -70 cbar treatment received considerably less than $\mathrm{Et}_{\text {. }}$.

$O$ nion yield and grade were far lower in 1998 than in 1997 due to severe hail 4 July that caused total defoliation and reduced the onion plants to short stubs 2 inches $(50 \mathrm{~mm})$ tall.

Reducing the SWP level after 15 July (during the last third of the growing season) below -20 cbar failed to reduce storage decomposition (Table
1). The percentage of decomposed bulbs was increased slightly in the -50 cbar treatment in 1998. Reducing the SWP level after 15 July to -50 cbar reduced colossal onion yield in 1997 and marketableand total yield in 1998. The increase in percent decomposition in 1998 with drier treatments could be related to the decrease in healthy bulb size in these treatments. Smaller bulbs may also hamper air circulation in storage thus favoring disease organism development.

Reducing irrigation so that the SWP was drier than -20 cbar had no beneficial effect on reducing bulb decomposition in storage, but it did reducetotal yield and theeconomic value of the crop. These results are in agreement with van Eeden and $M$ yburgh (1971) who found onion yields to be reduced by moisture stress in the last third of the growing season. $D$ ragland (1974) found onion yields were reduced and storage life unaffected by moisture stress during the last 3 weeks of the growing season. The economic value of an onion crop is often related to the proportion of larger sized bulbs, which were disproportionately decreased with irrigation criteria drier than -20 cbar after 15 July in the present study. Based on these results, irrigation of long-day onions should be continued until shortly before harvest.

\section{Literature cited}

Abreu, T.A.S., A.A. Millar, E.N. Choudhury, and M.M. Choudhury. 1980. Analise da produção de cebola sob differentes regimes de irrigação. Pesquisa A gropecuaria Brasileira 15:233-236.

Coelho, E.F., V.A.B. deSouza, and M .A.F. Conceição. 1996. O nion yieldsunder three water regimes and five spacings. Pesquisa A gropecuaria Brasileira 31:585-591.

D ragland, S. 1974. Nitrogen and water requirements in onions. Forsk. Fors. L andbruket. 26:93-113.

Klar, E .A., J.F. Pedras, and J.D . Rodrigues. 1976. Effect of various soil and climatic conditionson water requirement of onion. I. Yield of bulbs. Phyton 34:9-25.

Shock, C.C., E.B.G. Feibert, and L.D. Saunders. 1998a. O nion yield and quality affected by soil water potential asirrigation threshold. H ortScience 33:1188-1191.

Shock, C.C., J.M. Barnum, and M. Seddigh. 1998b. Calibration of Watermark soil moisture sensors for irrigation management. Irr. Assn. Proc. Intl. Irr. Show. San Diego, Calif. p. 139-146.

van Eeden, F.J. and J. M yburgh. 1971. I rrigation trials with onions. Agroplantae 3:57-62.

Wright, J.L. 1982. N ew evapotranspiration crop coefficients. J. Irr. D rain. Div., Amer. Soc. Civ. Eng. 108(1):57-74. 